УДК 81'373.45(045)

DOI https://doi.org/10.26661/2414-1135-2021-84-2

\title{
ПРАГМАТИКА ЗАПОЗИЧЕНЬ У РАМКАХ ДИСКУРСУ (НА ПРИКЛАДІ АНГЛІЦИЗМІВ В ІТАЛІЙСЬКІЙ МОВІ)
}

\author{
Бикова А. А. \\ аспірант кафедри іспанської та франиузької філологї \\ Київський національний лінгвістичний університет \\ вул. Велика Васильківська, 73, Київ, Украӥна \\ orcid.org/0000-0001-9179-3824 \\ all-italia@ukr.net
}

Ключові слова: мовний знак, комунікативний ефект, стилістичні сфери мови, евфемізм, прагматичний компонент.
Статтю присвячено питанню функціонально-прагматичної адаптації запозичень у мові-реципієнті. Розглядаються праці вітчизняних та зарубіжних дослідників, які вивчали процеси асиміляції іншомовних слів у новому мовному середовищі. Лінгвісти до недавнього часу намагалися описати та структурувати запозичення в основному за лексикосемантичними схемами. Але зараз мовознавча наука намагається вийти за рамки класичних досліджень і виокремити прагматичну інформацію про слово, що переплітається із семантичною. Тим більше, що відносно нових запозичень ієрархічність може змінюватися, і прагматична інформація може передувати семантичній, поступово входячи в лексичне значення слова. Індикатором цього явища $\epsilon$ в тому числі зміна прагматичного навантаження одного й того ж слова у різних типах дискурсу. Освоєння запозиченої лексики пов'язане із появою специфічних комунікативних моделей, що свідчать про різні етапи адаптації нового слова. Оскільки прагматика розглядає відношення між учасниками комунікації та мовними знаками, то важливим $є$ встановити причини, з яких іншомовні слова потрапляють до різних видів дискурсу. На прикладі італійської мови автор розглядає екстралінгвістичні фактори, що впливають на вибір засобами масової інформації англіцизмів для впливу на свідомість адресата. Створюючи текст, журналісти часто вдаються до маркованої лексики 3 метою підняти престиж того чи іншого об'єкта дискусії, приховати небажаний контент повідомлення та надати більшої ваги малозначущим явищам у суспільстві. Натомість у комп'ютерному дискурсі англіцизми вживаються передусім для позначення нових термінів та спрощення міжнародного спілкування спеціалістів у галузі інформатики, і тому прагматичний компонент у них практично відсутній. Те ж саме можна сказати і про офіційно-діловий та науковий дискурс. Таким чином, можна зробити висновок, що в італійській мові запозичення з англійської можуть зазнавати змін на рівні прагматичного компоненту лексичного значення, $\mathrm{i}$ що стилістичне забарвлення дискурсу є тією необхідною умовою, за якої можливе як набуття додаткового прагматичного значення, так і втрата початкового. 


\title{
PRAGMATICS OF BORROWING WITHIN DISCOURSE (ON THE EXAMPLE OF ENGLISH WORDS IN ITALIAN)
}

\author{
Bykova A. A. \\ Postgraduate Student at the Department of Spanish and French Philology \\ Kyiv National Linguistic University \\ Velyka Vasylkivska str., 73, Kyiv, Ukraine \\ orcid.org/0000-0001-9179-3824 \\ all-italia@ukr.net
}

Key words: communicative models, language sign, stylistic spheres of language, euphemism, pragmatic component.
The article is concerned with functional pragmatic adaptation of loanwords in the receiving language. The works of our country scientists and foreign researchers who studied the processes of assimilation of loanwords in a new language environment are analyzed. Until recently, linguists tried to describe and structure adopted words only according to lexical semantic schemes. But now they are trying to go over classical researches and to distinguish pragmatic information about the word, which is related with its semantic meaning. Moreover, that regarding to new loanwords, the hierarchy may be changed, and pragmatic information may precede the semantic one entering later in the lexical meaning of the word. The absorption of the borrowed words introduces some specific communicative models, indicating different phases of adaptation of the new word. Since pragmatics considers the relationship between participants of communication and language signs, it is important to define the reasons why foreign words get into different types of discourse. Changing pragmatical sense of the same word in different tipes of discuors can prove this phenomenon. On the example of the Italian language, the author analyses non-linguistic factors that influence the choice by the media of English loanwords to manipulate the consciousness of the addressee. When creating a text, journalists often use labeled vocabulary, in order to raise the prestige of a particular object of discussion, to hide unwanted content of a message and give more importance to insignificant phenomena in society. At the same time, in computer discourse, English words are used primarily to denote new terms and to simplify international communication between programmers, because of this they havn't got pragmatic component. The same can be said about the business and scientific discourse. Thus, we can conclude that borrowing from English in italian lenguage may change their pragmatic component of lexical meaning, and that the stylistic of discourse is a necessary condition which permeets to acquire additional pragmatic meaning and lose the original one.
Постановка проблеми. В останні десятиріччя увага до вивчення ролі англійських запозичень спричинена стрімким збільшенням їх кількості у всіх сферах мовленнєвої діяльності. Посилення глобалізації, поява інтернету та розквіт мас-медіа на рубежі тисячоліть сприяють тому, що потік англомовних слів через медійний простір проникає все глибше у внутрішню структуру кожної мови. Нерегульоване ї використання в різних типах дискурсу часто призводить до непорозуміння між мовцями, оскільки рівень володіння англійською мовою у комунікантів неоднаковий. Цей факт ще більше посилює прагматичне навантаження на цей тип лексики.

Аналіз останніх досліджень та публікацій. Процес запозичення іншомовної лексики був і залишається об'єктом дослідження багатьох вітчизняних та зарубіжних вчених: Л. Крисіна [1], В. Арістової [2], Л. Архипенко [3], В. Сімонок [4] та інших. Зокрема, прагматику запозичень вивчали Ф. Бацевич [5], Л. Гончаренко [6], Г. Дружин [7], В. Заботкіна [8], С. Мельник [9], С. Маніна [10], В. Рубан [11]. Проте прагматичний аспект мовної інтерференції залишається як ніколи актуальним у загальному спектрі вивчення проблеми.

Мета та завдання статті. Головна мета статті - визначити прагматику англомовних запозичень у різних типах дискурсу на прикладі італійської мови, а також варіювання прагматичного компоненту в порівнянні 3 оригінальним значенням. 
Об'єктом дослідження виступають лексичні запозичення 3 англійської мови. Предметом вивчення $\epsilon$ комунікативно-прагматичні характеристики англомовних запозичень у сучасній італійській мові.

Виклад основного матеріалу. Як відомо, мовний знак володіє не лише семантикою (відношенням до позначуваного) та синтактикою (відношенням до інших знаків), але й прагматикою (відношенням до користувача мови). Знаки мови можуть справляти на людей певне враження (позитивне, негативне чи нейтральне), мати на них якийсь вплив, викликати ту чи іншу реакцію. Здатністю проявляти певний комунікативний ефект володіє і будь-яке висловлювання, і будьякий текст. Характер такого впливу визначається трьома основними факторами:

1. Зміст висловлювання.

2. Сприйняття повідомлення залежить від характеру знаків, що складають висловлювання. Мовець під час побудови тексту добирає мовні засоби відповідно до свого наміру справити певне враження.

3. Прагматичний вплив висловлювання залежить від рецептора, що його сприймає.

Прагматичне значення - це відношення між знаком та людиною, суб'єктивне ставлення людей до одиниць мови, а через мову - до предметів та понять.

Прагматичне значення включає всі питання, пов'язані з різними ступенями розуміння тих чи інших мовних одиниць у мовленні або їх трактуванням залежно від мовного чи немовного досвіду людей, які беруть участь у процесі комунікації.

Що стосується запозичень, то лінгвісти до недавнього часу намагалися описати та структурувати їх лише за лексико-семантичними схемами. Але величезну кількість нових запозичень останніх років не завжди можна втиснути у рамки класичних методів досліджень, бо прагматична інформація про слово переплітається із семантичною. Але відносно нових запозичень ієрархічність може змінюватися, і прагматична інформація може передувати семантичній, поступово входячи в лексичне значення слова.

Звернення до фактів позамовного характеру дозволило перейти від номенклатури запозичених мовних одиниць до їх розгляду в умовах певного типу комунікативної ситуації. Формальна, функціональна і ситуативна інтерпретації запозичень зійшлись у дискурсі, як полі прагмалінгвістичного дослідження.

Дискурс - це складне комунікативне явище, що включає в себе крім тексту ще й екстралінгвістичні фактори (знання про світ, уявлення, установки, цілі адресанта), необхідні для розуміння тексту [12, с. 8$]$.
Презентаційна теорія дискурсу [13] заснована на філософському, психологічному, соціологічному розумінні потреб, які людина намагається реалізувати, вступаючи у комунікацію. Створюючи дискурс, мовець використовує необхідні мовні засоби у соціально-зумовленому процесі комунікації. Маючи деякі уявлення про предмет мовлення, адресант намагається сформувати схоже уявлення у адресата. Намічена ціль визначає напрям мовленнєвих дій.

Освоєння запозиченої лексики пов'язане із появою специфічних комунікативних моделей, що свідчать про різні етапи адаптації нового слова. Способи адаптації виявляються в ментальних структурах дискурсу як мовленнєвої події. В дискурсі містяться різні аспекти комунікації і по-різному проявляються міжсуб'єктні відносини.

Запозичене слово у публіцистиці, у різних видах і жанрах 3МІ являється не тільки засобом інформування, але й інструментом впливу. Завдяки запозиченню реальність може отримати особливий код, ціннісну соціальну орієнтованість, особливу оцінку з боку реципієнта.

Запозичення $є$ носієм напряму думок особистості, іiі свідомості. У дискурсі когнітивні установки адресанта, його інтенція повинні бути вербалізовані таким чином, щоб прямо чи опосередковано впливати на адресата - як безпосереднього співбесідника в реальному діалозі, так і гіпотетичного читача чи слухача.

Кожен учасник комунікації володіє власним набором знань, але для повноцінної інформації і результативного спілкування необхідно, щоб між адресантом і адресатом сформувалось певна згода, і вербально виражені знання одного були зрозумілі та прийняті іншим. Оскільки повного знання коду на ранньому етапі запозичення досягти важко, у дискурсі паралельно може подаватися набір характеристик нового слова або пошук синонімічних замін, які можуть об'єднати сукупні знання співбесідників. Асиметрія у знанні коду може пояснюватись багатьма причинами: віком, належністю до різних референтних груп, професій, ступенем освіти тощо. В ході дискурсу відбувається зміна та накопичення знань про денотат i, відповідно, уточнюється уявлення про семантичний об'єм запозиченого слова. Відбувається переміщення знань від одного суб'єкта до іншого і примноження загальних знань.

На початкових етапах освоєння запозиченого слова в процес активно включається компонент оцінки, який часто виявляється домінуючим. У цьому разі конотативне значення несе у дискурсі основне інформаційне навантаження. Міркування про семантику запозиченого слова можуть при цьому спиратися на суб'єктивні аргументи відповідно до конотативних ознак 
запозичення. Ось чому у дискурсі із новими запозиченнями вони часто інтенсифікуються через епітети, порівняння, метафори, словотворчу деривацію і синонімічні доповнення. Все це $\epsilon$ засобами компенсації смислової недостатності за допомогою прагматичних нюансів. Таким чином, можна вважати, що прагматичний фактор, який $\epsilon$ основним у дискурсі, відіграє провідну роль в освоєнні запозичень.

Слова, що прийшли з іншої мови, змінюються у свідомості людей, накладаються на індивідуальну картину світу, на стан суспільної свідомості певного часу, співвідносяться із поточними подіями. До своєї словникової фіксації у мові слово може довго перебувати у ситуативному, індивідуально забарвленому дискурсі.

Надання переваги запозиченню, а не більш зрозумілій і звичній одиниці, виявляє особливий когнітивний модус іноземного слова - створювати видимість, уявність. В цьому разі запозичення можна віднести до способів непрямого говоріння.

Творчі процеси у мовленнєвій діяльності, які втілюються мовцем і тим, хто його активно слухає і розуміє, Ю.М. Караулов співвідносить із глибинними властивостями мовної особистості, зорієнтованими не на звичайну комунікацію, а на прагматично направлену. Текстові перетворення, на думку Ю.М. Караулова, - це властивість будь-якого дискурсу, оскільки останній відкриває великі можливості для модальних реакцій у динаміці спілкування [14, с. 112-113]. Ситуативні інтенції, мотиви, установки - все це може бути проявлене у дискурсі через відношення комунікантів до запозиченого слова.

Одним із факторів, що впливають на семантичну структуру запозиченого слова, на зміну його семантики у певному напряму, є стилістичні сфери мови. У мові-джерелі слово може бути нейтральним, а у мові, що приймає, воно стає стилістично маркованим, набуває додаткового значення, яке починає впливати на самий лексичний зміст слова. В сфері запозичень стилістичний і власне лексичний компоненти не просто пов'язані один iз одним, але й знаходяться в особливій часовій детермінації: стилістичне начало проявляє себе до сформованості лексичного і часто визначає його.

Для запозичень характерне варіювання прагматичного компоненту лексичного значення, оскільки сама поява подібних лексичних одиниць у мові часто викликана причинами прагматичного характеру, i, відповідно, зміни на семантичному рівні, які відбуваються під час запозичення, стосуються насамперед сфери прагматики. Безперечно, не виключена i можливість збереження прагматики оригіналу.

Варіювання прагматичного навантаження можна прослідкувати під час співставлення зна- чення запозиченої одиниці в мові-джерелі та у мові-реципієнті. Співставляючи оригінальне значення запозичень англійського походження зі значенням в італійській мові, можна зробити висновок про ступінь прагматичної реалізації тієї чи іншої лексичної одиниці.

Як вважає О.Г. Беляєвська, прагматичний аспект - це частина лексичного значення, що виражає інформацію про комунікативну ситуацію. При цьому в прагматичному аспекті можна виділити такі підтипи:

1) Інформація про час та місце комунікативної ситуації може бути виражена за допомогою значення слова, яке вказує на положення мовця. Елемент часу, що передається прагматичним аспектом значення, встановлюється опосередковано.

2) Інформація про учасників ситуації передається за допомогою мови, якою вони користуються. Вона може вказувати на їх соціальне походження, положення, рівень освіти тощо. Прагматичний аспект слова може також передавати інформацію про соціальну систему даного мовного співтовариства, ідеологію, релігію тощо.

3) Зміст дискурсу вказує на те, як адресант (той, хто говорить) взаємодіє із адресатом (слухачем або читачем). Типи змістів базуються на соціальних чи сімейних ролях учасників комунікативної ситуації. Завдяки особливостям прагматичного аспекту слово може підходити для вживання в одному змісті і бути неприйнятним в іншому.

4) Стиль визначає загальний тип комунікативної ситуації, які за принципом формальності діляться на формальні, нейтральні та неформальні. Стиль співвідноситься зі змістом, визначаючи кожну конкретну комунікативну ситуацію. Практично кожне слово в мові є стилістично маркованим, тобто містить прагматичну інформацію про стиль, в якому воно може бути вжите [15].

Ступінь розповсюдження запозичень англійського походження у кожному виді дискурсу різний. Відповідно і ступінь прагматичної реалізації лексичних одиниць буде залежати від їх функціонування.

Запозичення англійського походження в італійській мові, які функціонують у ЗМІ, зазнають змін відповідно до основних характеристик цього дискурсу. До них належать економія мовних засобів, лаконічність викладу під час одночасного інформативного насичення, добір мовних засобів, які легко доходять до свідомості аудиторії. Завдяки цим характеристикам у масово-інформаційному дискурсі реалізуються умови, сприятливі для зміни прагматичного компоненту лексичного значення запозичень.

Вживання англіцизмів в оригінальній графічній формі у більшості випадків сприяє реалізації прагматичного компоненту слова, оскільки такі 
лексичні одиниці отримують у процесі комунікації нове стилістичне забарвлення. Наприклад: L'Enel sta per diventare una vera public company senza il proprio maggiore quotista (Enel стоїть перед завданням перетворитися на справжню громадську компанію без свого головного акціонера). За визначенням Oxford Business English Dictionary public company - це компанія, акції якої продаються на біржі [16]. У лексичне значення цього слова закладений прагматичний компонент стилістичного маркування, який підходить для використання цього слова в економічній тематиці. Під час вживання в оригінальній графічній формі без перекладу вказується на інтелектуальний рівень учасників комунікації як людей, що оперують економічною термінологією англійської мови, тобто вираз набуває додаткового прагматичного навантаження.

Окремим випадком використання запозиченої лексики є вживання англіцизмів у якості евфемізмів. Це продиктовано умовами розвитку суспільства, де іншомовні слова та терміни використовуються для приховування істинної суті явища. Ще в середині XX ст. С. Відлак відмічав, що іншомовна лексика частіше, ніж рідна фігурує як евфемізм, оскільки «іншомовні слова менш шокують і здаються благороднішими» [17, с. 44-52]. Як відмічає О.Й. Шейгал, евфемізація являє собою стратегію вуалювання, маскування небажаної інформації, що дозволяє зробити менш очевидними неприємні факти [18]. Так, евфемістичне позначення назв деяких професій за допомогою англіцизмів має на меті підвищити їх престижність. Мета досягається завдяки достатньо високому соціальному статусу осіб, що володіють англійською мовою, i зумовлюється проникненням лексики глобальної англійської мови в усі сфери італійської мовної спільноти. Прикладом вуалювання може служити англіцизм receptionist - «секретар», який зустрічається передусім у текстах об'яв і $є$ дублетом італійського слова segretario/a, але соціально більш значимим, оскільки у свідомості мовців іншомовна назва професії асоціюється з високооплачуваною роботою в іноземній компанії, а значить являється більш престижною. Таким чином, лексичне значення слова receptionist отримує в італійській мові додаткове прагматичне навантаження з точки зору встановлення соціальних ролей, а скромний співробітник готелю, що приймає клієнтів, набирає більшої ваги в італомовному суспільстві у порівнянні зі своїм західним колегою. Аналогічна ситуація спостерігається і з вживанням назв інших професій: manager - «менеджер», merchandiser - «товарознавець».

Іншим прикладом англійського терміну з італійським еквівалентом $є$ слово leader (іт. саро), яке зустрічається повсюди в пресі і має значення «керівник, наставник в сфері політики, праці і воєнної справи». Воно було введене в італійську мову в дев'ятнадцятому сторіччі і має більш конотативне значення, ніж денотативне, тому що посилається на англосаксонський світ, де успішно розвивалася політика, сфера праці і накопичувалась військова сила, що позитивно сприймалося рештою західного світу. Проте його постійне вживання в пресі надає йому ще й іншого значення - афективного, тобто читачі мають відчувати, що вони захищені і живуть у сильній країні. Отже, автор може передавати конкретні послання, що стають підгрунтям віри у новий справедливий світ. При цьому роль запозичень посилюється саме завдяки ïx екзотичному конотативному навантаженню, яке виражає певні історичні, соціальні та культурні цінності.

Цей факт може, наприклад, пояснити надмірну присутність англіцизмів у сфері моди. В італійській мові предмети одягу, названі англійськими термінами, автоматично набирають ваги й стають престижними, так само як трапляється і 3 італійськими термінами в англійській мові. Таким чином, користуючись семантичною та прагматичною структурою терміна, журналіст ставить ще й на формальний аспект, оскільки, будучи іншомовним у очах читачів, слово справляє більш яскраве враження на текстуальному рівні.

Отже, масово-інформаційний дискурс не тільки являється однією зі сфер функціонування запозиченої лексики і служить ії провідником у інші галузі, але й $є$ тією областю, в якій реалізуються умови зміни прагматичного компоненту у складі лексичного значення.

Комп'ютерний дискурс, який являє собою спілкування спеціалістів у сфері комп'ютерних технологій, взаємодіє із масово-інформаційним, слугуючи для нього джерелом специфічної комп'ютерної лексики. У ЗМІ, які описують досягнення в сфері комп'ютерних технологій, достатньо часто використовується запозичена лексика, причому не тільки та, яка належить до комп'ютерного жаргону.

Комп'ютерна грамотність передбачає володіння англійською мовою, на яке орієнтуються автори публікацій. У спеціальних виданнях англіцизми не зазнають змін, оскільки використовуються для описання нових чи вже існуючих явищ комп'ютерного світу і належать до сфери термінології, зберігаючи таким чином оригінальну прагматику під час вживання в італійській мові.

У комп'ютерному дискурсі вживання запозиченої лексики у початковій графічній формі без перекладу служить для полегшення спілкування, тому зустрічається доволі часто. Спрощення спілкування досягається за рахунок того, що інтернаціональним $є$ не тільки значення вжитих слів, 
а й їх форма. Зазвичай без перекладу вживаються назви програмних продуктів (Word, Excel) і понять із сфери комп'ютерного спілкування, що відомі більшості користувачів саме в такому вигляді (URL, hotmail, e-mail). У цьому разі прагматичний компонент залишається незмінним. Зміна прагматичного компоненту можлива в особливому контекстному оточенні, під час переосмислення початкового значення і під час утворення похідних слів.

До особливостей офіційно-ділового дискурсу належать стабільність, традиційність і стандартизованість, оскільки сферою його застосування $\epsilon$ ділові відносини між людьми, закладами і державами. Через те, що офіційно-діловий дискурс характеризується строгою точністю, об'єктивністю, конкретністю, лаконічністю, відсутністю образності та емоційності, вибір мовних засобів для нього буде визначатися цими особливостями. Зокрема, використання запозичених лексичних одиниць не буде продиктоване прагненням до реалізації основних прагматичних установок, оскільки виражений у офіціально-діловому стилі зміст має виключати двозначність і можливість непорозуміння: Nel suo primo business plan c'erano 100 persone, la cifra un po' esagerata (У його першому бізнес-плані було 100 чоловік, трохи перебільшена цифра). Основні характеристики виразу business plan - належність до економічної термінології і відсутність емоційного забарвлення зберігаються при його запозиченні в італійську мову. Іншими словами, прагматичний компонент залишається незмінним.

Таким чином, можна дійти висновку про загальну тенденцію до збереження оригінальної прагматики англіцизмів у офіційно-діловому дискурсі, що пояснюється такими його особливостями, як об'єктивність, конкретність та відсутність образності. Подібні параметри характерні i для наукового дискурсу, в якому також зберігається прагматика запозичених лексичних одиниць, оскільки для нього не характерна наявність умов, що впливають на варіювання прагматичного компоненту лексичного значення запозичень.

Висновки і перспективи подальших досліджень. Як бачимо, під час функціонування в італійській мові запозичення англійського походження можуть зазнавати змін на рівні прагматичного компоненту лексичного значення. За наявності необхідних умов можливе як набуття додаткового прагматичного значення, так і втрата початкового. У протилежному випадку оригінальна прагматика зберігається.

У перспективі дослідження варто розібратися, як впливає на прагматику запозичення канал надходження інформації - усний чи письмовий. Адже відомо, що під час усного мовлення варіація праг- матичного контенту слова значно ширша, ніж у разі його письмової фіксації. Слід звернути також увагу на все більш популярний інтернет-дискурс, куди входить мова блогів, соцмереж та месенджерів, оскільки він $є$ гібридним варіантом усно-письмового мовлення.

\section{ЛІТЕРАТУРА}

1. Крысин Л.П. Русское слово, свое и чужое: Исследования по современному русскому языку и социолингвистике. Москва, 2004. 883 с.

2. Аристова В.М. Англо-русские языковые контакты (англицизмы в русском языке). Ленинград : ЛГУ, 1978. 150 с.

3. Архипенко Л.М. Іншомовні лексичні запозичення в українській мові: етапи і ступені адаптації (на матеріалі англіцизмів у пресі кінця XXI ст.) : автореф. дис. канд. філолог. наук : 10.02.01. Харків, 2005. 28 с.

4. Сімонок В.П. Запозичена лексика в українській мовній картині світу. Науковий вісник Херсонського державного університету. Перекладознавство та міжкультурна комунікація. 2016. Вип. 2. С. 96-102. URL: http:// nbuv.gov.ua/UJRN/nvxdupmk 2016 222.

5. Бацевич Ф.С. Вступ до лінгвістичної прагматики. Підручник. Київ : Академія, 2011. 304 с.

6. Гончаренко Л.О. Функціональний аспект запозичень. Актуальні проблеми слов'янської філології. 2010. Вип. XXIII (част. 4). C. 294-301.

7. Дружин Г.В. Сучасні лексичні запозичення: прагматика, семантика, соціолінгвістика : автореф. дис. канд. філ. наук : 10.10.02. Дніпропетровськ, 2006. $32 \mathrm{c}$.

8. Заботкина В.И. Семантика и прагматика нового слова (на материале английского слова) : дис. док. фил. наук : 10.02.04. Москва, 1991. $372 \mathrm{c}$.

9. Мельник С.М. Прагматичні функції іншомовних вкраплень в українській прозі кінця XX - початку XXI століть. Наукові записки Національного університету «Острозька академія». 2014. С. 258-260.

10. Манина С.И. Прагматические функции иноязычных вкраплений. Вестник Adblгейского государственного университета. Серия 2 : Филология и искусствоведение. 2010. URL: https://cyberleninka.ru/article/n/ pragmaticheskie-funktsii-inoyazychnyhvkrapleniy

11. Рубан В.О. Лінгво-прагматичні функції англійських запозичень у сучасному французькому медіа-дискурсі. Науковий вісник Чернівецького університету. Романо-слов'янський дискурс. 2012. Вип. 598. С. 43-48. URL: http:// nbuv.gov.ua/UJRN/Nvchu_rsd_2012_598_11. 
12. Петров В.В., Караулов Ю.Н. Вступительная статья. Язык. Познание. Коммуникаиия. Москва : Прогресс, 1989. 5-11 с.

13. Олянич Н.В. Презентационная теория дискурса : монография. Волгоград : Парадигма, 2004. $507 \mathrm{c}$.

14. Караулов. Ю.Н. Русский язык и языковая личность. Москва : Наука, 1987. 261 с.

15. Беляевская Е.Г. Семантика слова. Москва : Высш. школа, 1987. 128 с.

16. Oxford Business English Dictionary. Dilys Parkinson .Oxford University Press. 2006. 608 p.

17. Видлак С. Проблема эвфемизма на фоне теории языкового поля. Этимология. 1965. Москва : Наука, 1967. 44-52 с.

18. Шейгал Е.И. Семиотика политического дискурса. Москва, Волгоград : Перемена, 2000. $368 \mathrm{c}$.

\section{REFERENCES}

1. Krysin L.P. (2004). Russkoe slovo, svoe i chuzhoe: Issledovanija po sovremennomu russkomu jazyku i sociolingvistike [Russian word, the own one and the foreign one]. Studies on the modern Russian language and sociolinguistics. Moscow, p. 883 (in Russian).

2. Aristova V.M. (1978). Anglo-russkie jazykovye kontakty (anglicizmy v russkom jazyke) [English and Russian language contacts (english borrowings in Russian language)]. Leningrad: LSU, p. 150 (in Russian).

3. Arkhypenko L.M. (2005). Inshomovni leksychni zapozychennia $\mathrm{v}$ ukrainskii movi: etapy $\mathrm{i}$ stupeni adaptatsii (na materiali anhlitsyzmiv $\mathrm{u}$ presi kintsia XXI st.) [Loanwords in Ukrainian language: stages and degrees of adaptation (on the material of english borrowings in the press of the end 21st century)]. (PhD Thesis). Kharkiv, p. 28.

4. Simonok V.P. (2016). Zapozychena leksyka v ukrainskii movnii kartyni svitu [Borrowings in the Ukrainian linguistic picture of the world.]. Naukovyy visnyk Khersonskoho derzhavnoho universytetu [Scientific Journal of Kherson State University], vol. 2. URL: http://nbuv.gov.ua/ UJRN/nvxdupmk_2016_2_22.

5. Batsevych F. S. (2011). Vstup do linhvistychnoi prahmatyky [Introduction to linguistic pragmatics]. Kyiv: Academia, p. 304 .

6. Honcharenko L.O. (2009). Linhvoprahmatychnyi aspekt publitsystychnykh zapozychen [Pragmatic aspects of journalistic borrowings]. Kirovohrad : Science notes, v. 81, no. 3, pp. 255-259.
7. Druzhyn H.V. (2010). Suchasni leksychni zapozychennia: prahmatyka, semantyka, sotsiolinhvistyka [Modern lexical borrowings: pragmatics, semantics, sociolinguistics]. (PhD Thesis). Dnipropetrovsk, p. 32 .

8. Zabotkyna V.Y. (1991). Semantyka i prahmatyka novogo slova (na materiale anhliyskoho slova) [Semantics and pragmatics of Modern Word (on the material of the English language)]. ( $\mathrm{PhD}$ dissertation). Moscow, p. 372. (in Russian)

9. Melnyk S.M. (2014). Prahmatychni funktsii inshomovnykh vkraplen v ukrainskiy prozi kintsia XX - pochatku XXI stolit [Pragmatic functions of foreign words in Ukrainian prose at the end the XX - the beginning of the XXI centuries]. Scientific Journal of the National University of Ostroh Academy, pp. 258-260.

10. Manina S.I. (2010). Pragmaticheskie funkcii inojazychnyh vkraplenij [Pragmatic functions of foreign words]. Journal of the Adygea State University (electronic journal), vol. 2. (in Russian). URL: http//cyberleninka.ru/ article/n/pragmaticheskie-funktsiiinoyazychnyh vkrapleniy.

11. Ruban V. (2012) Lingvo-pragmatychni funktsii angliyskykh zapozychen $u$ suchasnomu frantsuzkomu media-dyskusi. [Pragmatic functions of english borrowings in the modern french media-discours]. Journal of Chernivtsy University. Pp. 43-48. URL: http://nbuv.gov.ua/ UJRN/Nvchu rsd 201259811.

12. Petrov V.V., Karaūlov Y.N. (1989) Vstupitelnaya statya [Introductory article]. Language. Knowledge. Communication. Progress, pp. 5-11. (in Russian).

13. Olyanych N.V. (2004) Presentazyonnaya teoria diskursa [Presentation theory of discourse]. Paradigma, pp. 507. (in Russian).

14. Karaulov Y.N. (1987) Russkiy yazyk i yazykovayz lichnost [Russian language and language identity]. Science, pp. 261. (in Russian).

15. Belyaevskaya E.G. (1987) Semantika slova [Semantics of the word]. Vysshaya shkola, pp. 128. (in Russian).

16. Oxford Business Englich Dictionary (2006) Oxford University Press. pp. 608.

17. Vydlak S.P. (1967) Problema eufemisma na fone teorii yazikovogo polya [The problem of euphemism in the background of the theory of the language field]. Ethymology. Moscow. Science, pp. 44-52. (in Russian).

18. Sheigal E.I. (2000) Semiotics of political discourse [Semiotica politicheskogo diskursa]. Peremena, pp. 368. (in Russian). 